\title{
EGG TRANSFER IN THE COW: PREGNANCY RATE AND EGG SURVIVAL
}

\author{
J. M. SREENAN AND D. BEEHAN \\ The Agricultural Institute, Belclare, Galway, Ireland
}

(Received 13th Fune 1974)

Apart from the results reported by Rowson, Moor \& Lawson (1969), Rowson, Lawson \& Moor (1971) and Rowson, Lawson, Moor \& Baker (1972), no data are available on pregnancy rates following the surgical transfer of fertilized cow eggs. Rowson et al. (1969) recorded a pregnancy rate of $91 \%$ in a group of eleven heifers, each of which received either two or three fertilized eggs transferred to the uterine horn adjacent to the ovary carrying the corpus luteum. No incidence of twinning was recorded following these transfers. Rowson et al. (1971) reported a twinning rate of $50 \%$ following the transfer of one fertilized egg to each uterine horn in eighteen recipients. The total egg survival in this study was $61 \cdot 1 \%$. When both the donor and recipient were in oestrus on the same day, however, the corresponding rates were $71.4 \%$ and $78.6 \%$. The necessity for close synchronization to achieve high pregnancy rates was again shown by Rowson et al. (1972) when they reported a pregnancy rate of $91.1 \%$ following transfers where the donor and recipient came into oestrus on the same day. This pregnancy rate fell to just over $50 \%$ when the donors and recipients were out of phase by 1 day. Studies are in progress to determine some of the factors which affect the outcome following the surgical recovery of fertilized eggs from donor animals after superovulation and the transfer, both surgical and non-surgical, of one fertilized egg to each uterine horn in recipient animals. This communication deals with pregnancy rate and egg-survival, following surgical transfers in heifers.

Superovulation was induced in donor animals (Hereford cross heifers, 290 to $382 \mathrm{~kg}$ ) either by (1) intramuscular injection of 2500 i.u. PMSG (Intervet) on Day 16 of the oestrous cycle and intravenous injection of 2000 i.u. HCG (Intervet) on the day of oestrus or on Day 21, or (2) by intramuscular injection of 1500 or 2500 i.u. PMSG on Day 10 of the oestrous cycle followed by intramuscular injection of $700 \mu \mathrm{g}$ prostaglandin analogue 79,939 (I.C.I.) on Day 12 and a further $200 \mu \mathrm{g}$ on Day 13. Heifers were inseminated in late oestrus either by natural mating or by artificial insemination (frozen semen). Recipients were naturally cyclic heifers found to be in oestrus on the same day (Day 0) or 1 day later $(-1)$ than the donors.

Between 4 and 8 days after insemination, donor heifers were anaesthetized with pentobarbitone sodium, followed by closed circuit anaesthesia using fluothane and oxygen. Entry to the pelvic cavity was made through a mid-line incision. Both uterine horns were flushed through the oviducts and ova were collected through a polyethylene cannula inserted into the oviducts. The 
flushing medium used was sterile TCM 199 (Biocult) based on either Hanks or Earles basic salt solution and buffered by either sodium bicarbonate or Hepes buffer. Following flushing into glass collection cups, examination under a stereoscopic microscope was carried out in a specially constructed cabinet at $35^{\circ} \mathrm{C}$. Eggs were placed in TCM 199 in an incubator at $37 \pm 1^{\circ} \mathrm{C}$ and held until transfer.

Recipient heifers were anaesthetized in a similar manner to that used for donors and the uterine horns were exposed through a mid-line incision. One, two or three eggs were then transferred to each recipient. Single eggs were transferred to the uterine horn adjacent to the corpus luteum. Where two eggs were transferred one was placed in each uterine horn. Transfer was carried out by drawing the eggs into a Pasteur pipette and depositing them in the uterine horn approximately 20 to $25 \mathrm{~mm}$ from the uterotubal junction. Recipient heifers were either slaughtered at 40 days or palpated at 60 days to ascertain the presence or absence of pregnancy. The results of the transfers in terms of pregnancy rates are given in Table 1 .

Table 1. Pregnancy rate following surgical transfers in cattle

\begin{tabular}{c|c|c|c}
\hline $\begin{array}{c}\text { Degree of } \\
\text { synchronization } \\
\text { (days) }\end{array}$ & $\begin{array}{c}\text { No. of } \\
\text { recipients }\end{array}$ & $\begin{array}{c}\text { No. } \\
\text { pregnant }\end{array}$ & $\%$ Pregnant \\
\hline 0 & 24 & 22 & 91.7 \\
-1 & 7 & 5 & 71.4 \\
\hline
\end{tabular}

The pregnancy rates obtained of 91.7 and $71.4 \%$ for synchronous and asynchronous transfers, respectively, are in good agreement with the corresponding values of 91.1 and $52.2 \%$ reported by Rowson et al. (1972). A total of twentythree recipients were slaughtered at 40 days to provide data on egg survival rates (Table 2).

Table 2. Egg survival rates following surgical transfers in cattle

\begin{tabular}{c|c|c|c|c|c|c}
\hline $\begin{array}{c}\text { Degree of } \\
\text { synchronization } \\
\text { (days) }\end{array}$ & $\begin{array}{c}\text { No. of heifers } \\
\text { killed }\end{array}$ & $\begin{array}{c}\text { Total no. of eggs } \\
\text { transferred }\end{array}$ & $\begin{array}{c}\text { No. of } \\
\text { embryos } \\
(40 \text { days })\end{array}$ & $\begin{array}{c}\% \text { Egg } \\
\text { survival }\end{array}$ & $\begin{array}{c}\text { No. of } \\
\text { recipients } \\
\text { with twins }\end{array}$ & $\begin{array}{c}\% \\
\text { recipients } \\
\text { with twins }\end{array}$ \\
\hline 0 & 16 & 33 & 27 & $81 \cdot 8$ & 12 & $75 \cdot 0$ \\
-1 & 7 & 10 & 6 & $60 \cdot 0$ & 1 & $33 \cdot 3$ \\
\hline
\end{tabular}

The data on twinning and egg survival rates obtained in this study are in close agreement with the values, 71.4 and $78.6 \%$ respectively, reported by Rowson et al. (1971), and confirm the feasability of achieving high pregnancy rates in cattle following surgical recovery and transfer of fertilized eggs.

Little information is available in the literature on fetal loss in twin-bearing cows or heifers. Gordon, Williams \& Edwards (1962) reported a loss of $9.2 \%$ following positive diagnosis at 42 days. The data of Rowson et al. (1971) suggest a loss of $10 \%$ from 42 days onwards. It would appear from this that the 
high pregnancy and egg survival rates reported here would sustain approximately a $10 \%$ loss up to calving.

We thank Mr M. J. Cooper, I.C.I. Ltd, for the prostaglandin analogue, I.C.I. 79,939 .

\section{REFERENGES}

Gordon, I., Williams, G. \& Edwards, J. (1962) The use of serum gonadotrophin (PMS) in the induction of twin pregnancy in the cow. 7. agric. Sci., Camb. 59, 143.

Rowson, L. E. A., Lawson, R. A. S. \& Moor, R. M. (1971) Production of twins in cattle by egg transfer. F. Reprod. Fert. 25, 261.

Rowson, L. E. A., Lawson, R. A. S., Moor, R. M. \& Baker, A. A. (1972) Egg transfer in the cow: synchronization requirements. F. Reprod. Fert. 28, 427.

Rowson, L. E. A., Moor, R. M. \& Lawson, R. A. S. (1969) Fertility following egg transfer in the cow; effect of method, medium and synchronization of oestrus. F. Reprod. Fert. 18, 517. 